\title{
LAPORAN KEUANGAN
}

Makalah Ini Disusun untuk Memenuhi Tugas pada Mata Kuliah Kewirausahaan

Dosen Pengampuh : Dra. Hj. Nuraeni Gani, MM.

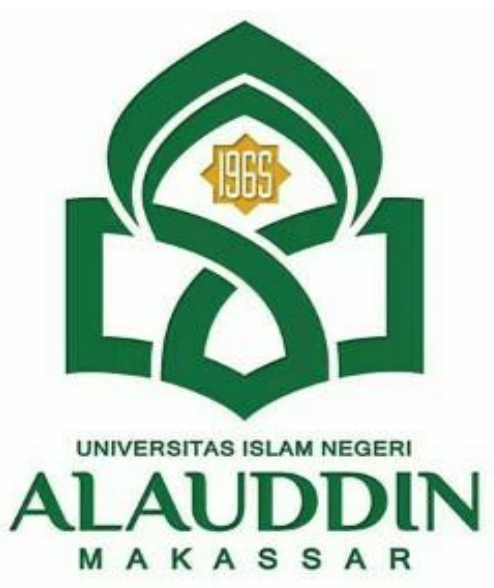

\author{
RAHMI \\ 90500120121 \\ rahmi@gmail.com
}

PRODI PERBANKAN SYARIAH

FAKULTAS EKONOMI DAN BISNIS ISLAM UNIVERSITAS ISLAM NEGERI ALAUDDIN MAKASSAR

TAHUN 2021 


\begin{abstract}
ABSTRAK
Dalam suatu perusahaan atau organisasi ada beberapa aspek-aspek yang harus disusun dan diperhatikan dengan baik. Salah satunya adalah dengan menyusun laporan keuangan yang bertujuan untuk mengetahui jumlah harta atau aktiva yang dimiliki perusahaan, kewajiban yang harus dibayar, modal, dan beberapa beban biaya yang harus dipenuhi perusahaan, juga untuk mengetahui untung ruginya usaha yang dijalankan oleh perusahaan atau organisasi.Adapun dalam menyusun laporan keuangan terdapat beberapa tahap yaitu yang pertama menyusun laporan neraca, laba-rugi, arus kas, dan laporan perubahan modal.
\end{abstract}

Kata kunci: Laporan Keuangan, Neraca, Laba-Rugi, Arus Kas, Perubahan Modal 


\section{KATA PENGANTAR}

Puji syukur kehadirat Allah SWT yang telah memberikan rahmat dan hidayahNya sehingga saya dapat menyelesaikan tugas makalah yang berjudul "Laporan Keuangan" ini dengan tepat waktu. Adapun tujuan dari makalah ini adalah untuk memenuhi tugas pada mata kuliah Kewirausahaan. Selain itu, makalah ini bertujuan untuk menambah wawasan tentang bagaimana manfaat Laporan Keuangan bagi para pembaca dan juga penulis.

Saya mengucapkan terima kasih kepada Ibu Dra. Hj. Nuraeni Gani, MM, selaku dosen yang telah memberikan tugas ini sehingga dapat menambah pengetahuan dan wawasan sesuai bidang yang saya tekuni.

Makalah yang saya tulis ini masih jauh dari kata sempurna. Oleh karena itu, kritik dan saran yang membangun akan saya nantikan demi kesempurnaan makalah ini.

Toraja, 11Des 2021

Rahmi 


\section{DAFTAR ISI}

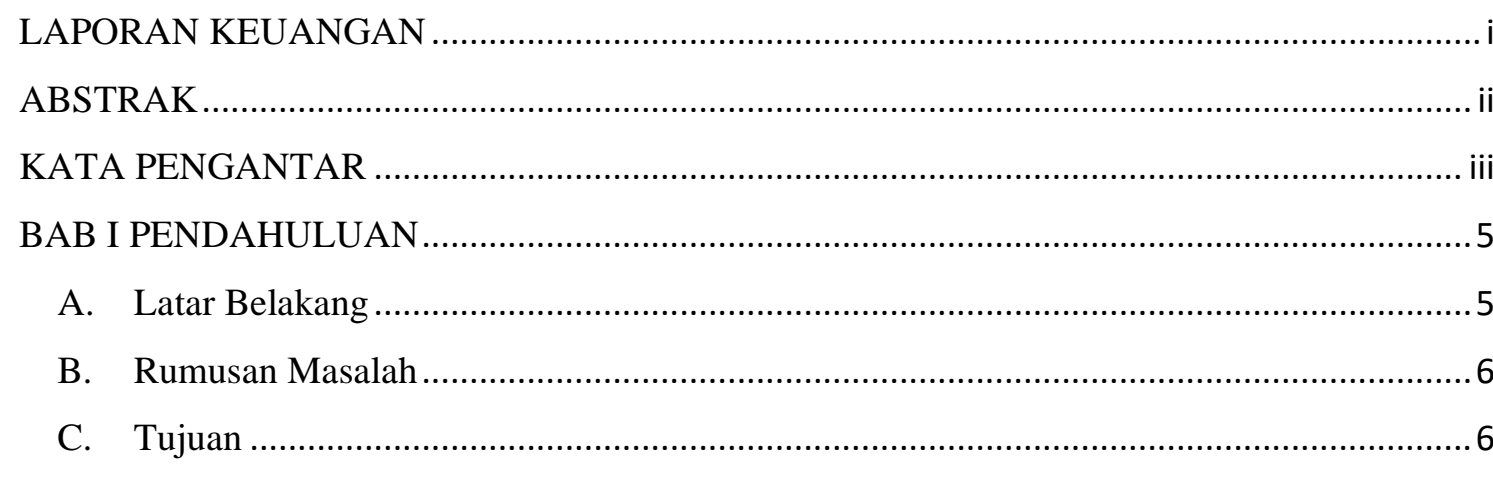

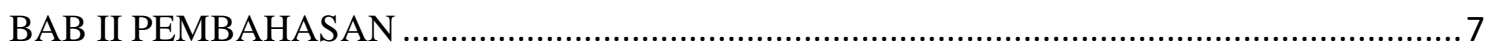

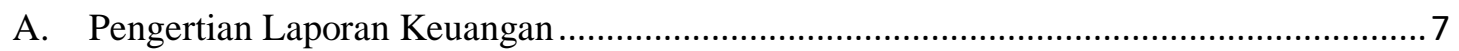

B. Pengguna Laporan Keuangan (Berkepentingan) ..........................................................

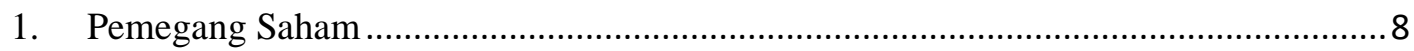

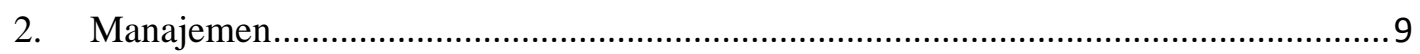

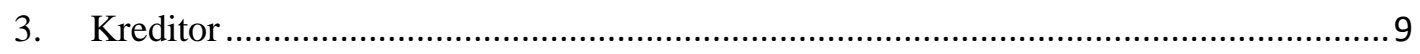

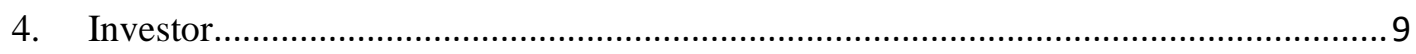

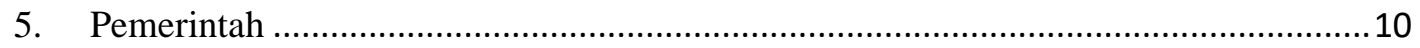

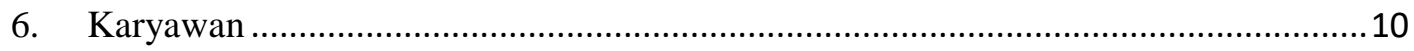

C. Jenis-jenis Laporan Keuangan ...................................................................................

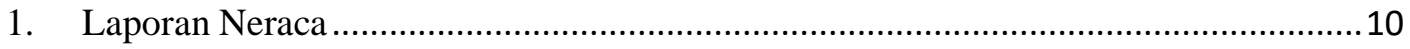

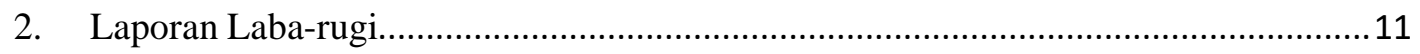

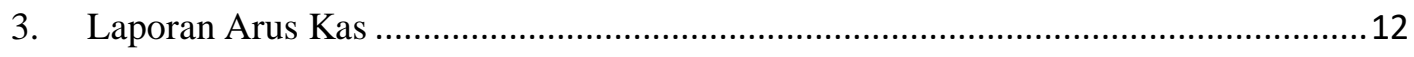

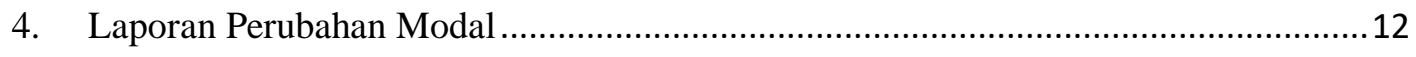

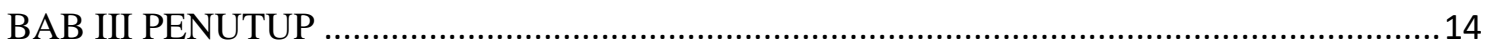

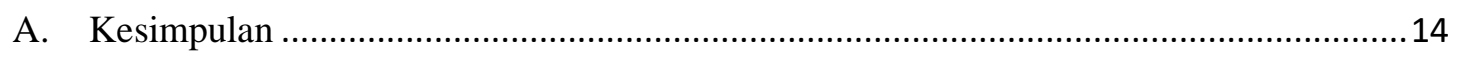

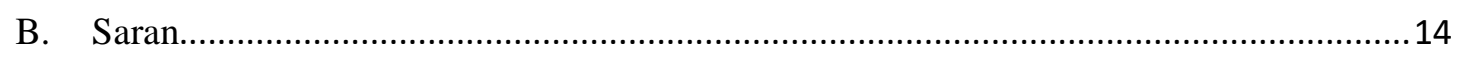

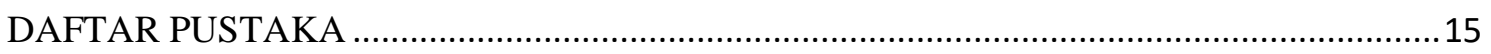




\section{BAB I \\ PENDAHULUAN}

\section{A. Latar Belakang}

Laporan keuangan merupakan salah satu aspek yang paling penting dalam pengelolaan usaha perusahaan atau organisasi. Berhasil tidaknya usaha yang dilakukan oleh perusahaan juga karena pengaruh laporan keuangan. Untuk itu perusahaan memang harus memilih sumber daya manusia yang memang ahli dalam menyusun laporan keuangan. Dalam tahap penyusunan laporan keuangan harus dilakukan dengan teliti dan oleh orang yang memang benar mengerti tentang cara menyusun laporan keuangan.

Tahap pertama dalam menyusun laporan keuangan yaitu dengan membuat laporan neraca yang bertujuan agar perusahaan mengetahui posisi keuangan, seperti posisi aktiva, kewajiban, modal suatu perusahaan pada waktu tertentu. Tahap kedua, yaitu membuat laporan laba rugi dengan tujuan mengetahui keuntungan atau pendapatan yang diperoleh oleh perusahaan juga biaya-biaya yang dikeluarkan selama satu periode tertentu. Tahap ketiga, yaitu laporan arus kas yang dibuat agar perusahaan mengetahui aspek-aspek apa saja yang berkaitan dengan kegiatan dalam perusahaan. Tahap ke empat, yaitu laporan perubahan modal yang bertujuan untuk mengetahui perubahan modal yang terjadi dalam perusahaan.

Ada beberapa pihak yang berkepentingan atau memerlukan laporan keuangan perusahaan yaitu, pemegang saham, manajemen, kreditor, investor, pemerintah, dan karyawan. 


\section{B. Rumusan Masalah}

1. Apa pengertian Laporan Keuangan?

2. Siapa saja pihak yang berkepentingan dengan laporan keuangan perusahaan?

3. Apa saja jenis-jenis laporan keuangan?

\section{Tujuan}

1. Untuk mengetahui dan memahami pengertian Laporan Keuangan.

2. Untuk mengetahui dan memahami siapa saja pihak yang memiliki kepentingan terhadap laporan keuangan perusahaan.

3. Untuk mengetahui dan memahami jenis-jenis laporan keuangan. 


\section{BAB II}

\section{PEMBAHASAN}

\section{A. Pengertian Laporan Keuangan}

Laporan keuangan dapat diartikan secara umum yaitu sebuah laporan yang dilakukan yang didalamnya terdapat rincian-rincian baik itu aset, kewajiban, modal, sampai biaya-biaya yang dikeluarkan oleh perusahaan dengan tujuan untuk mengetahui kondisi keuangan perusahaan dalam satu periode tertentu.

Ikatan AkuntanIndonesia (2012:5)mengemukakan pengertianlaporan keuanganmerupakanstruktur yang menyajikanposisi keuangan dan kinerjakeuangan dalamsebuahentitas.

Berikut beberapa pengertian Laporan Keuangan menurut para ahli :

1. Menurut Kasmir (2014:6), laporan keuangan didefinisikan sebagai laporan yang menunjukkan kondisi keuangan perusahaan pada saat ini atau dalam suatu periode tertentu.

2. MenurutKieso, dkk (2007:2), Laporan Keuangan merupakan sarana yang bisa digunakan oleh entitas untuk mengkomunikasikan keadaan terkait dengan kondisikeuangannya kepada pihak- pihak yang berkepentingan baik yang berasal dari internal entitas maupun eksternal entitas.

3. Harahap (2009:105) mengemukakan bahwa laporan keuangan menggambarkan kondisi keuangan dan hasil usaha suatu perusahaan pada saat tertentu atau jangka waktu tertentu. Adapun jenis laporan keuangan yang lazim dikenal adalah neraca, laporan laba-rugi atauhasil usaha, laporan perubahan ekuitas, laporan aruskas, laporan posisi keuangan. 
4. Menurut Soemarsono (2004:34), Laporan Keuangan adalah laporan yang dirancang untuk para pembuat keputusan, terutama pihak diluar perusahaan, mengenai posisi keuangan dan hasil usaha perusahaan.

Tujuan umum darilaporan keuangan ini untukkepentingan umum adalahpenyajian informasi mengenaiposisi keuangan (financialposition), kinerja keuangan(financialperformance), danarus kas (cashflow) dari entitasyang sangat berguna untukmembuat keputusan ekonomisbagi para penggunanya. Laporan keuangan bertujuan sebagai suatupertanggungjawaban pihak manajemen atas penggunaan sumberdaya yang dipercayakan kepada mereka.

\section{B. Pengguna Laporan Keuangan (Berkepentingan)}

Salah satu tujuan perusahaan menyusun laporan keuangan adalah untuk memudahkan para pengguna atau yang berkepentingan terhadap laporan keuangan perusahaan. Berikut beberapa pihak-pihak yang berkepentingan terhadap dibuatnya laporan keuangan :

\section{Pemegang Saham}

Pemegang saham merupakan salah satu pihak yang sangat berkepentingan terhadap suatu laporan keuangan. Laporan keuangan berfungsi sebagai salah satu aspek yang dijadikan pemegang saham untuk melihat kondisi keuangan perusahaan. Itulah mengapa Laporan Keuangan sangat perlu disusun dalam sebuah perusahaan. Terutama jika pemegang perusahaan memberikan pimpinannya kepada orang lain, maka Laporan Keuangan sangat dibutuhkan agar pemegang saham bisa menilai sukses atau tidaknya manajer tersebut. Jika manajer tersebut berhasil mendapatkan laba sesuai yang diharapkan maka manajer tersebut akan tetap diberikankepercayaan untuk mengendalikan perusahaan. 


\section{Manajemen}

Hal yang penting bagi manajemen adalah bahwa laporan keuangan tersebut bisa dijadikan sebagai bentuk pertanggungjawaban kepada para pemilik perusahaan agar dapat dipercayai. Selain itu Laporan Keuangan dapat dimanfaatkan pihak manajemen untuk mengukur tingkat biaya dari berbagai kegiatan perusahaan, untuk menentukan derajat keuntungan yang dapat dicapai oleh perusahaan yang bersangkutan, untuk mengukur daya kerja tiap individu atau pihak yang diberikan kepercayaan dalam menyusun laporan keuangan, dan lain sebagainya.

\section{Kreditor}

Laporan keuangan perusahaan berfungsi sebagai acuan yang dapat digunakan oleh para kreditor untuk menentukan apakah akan memberi atau menolak permintaan kredit dari perusahaan tersebut. Hal ini akan dilakukan baik oleh kreditor jangka pendek ataupun kreditor jangka panjang. Dengan melihat Laporan Keuangan perusahaan, kreditor akan mengetahui tingkat kemampuan perusahaan tersebut untuk membayar kredit perusahaannya.

\section{Investor}

Investor merupakan salah satu pihak yang akan terlibat dalam berjalan lancarnya usaha perusahaan. Karena investor merupakan pihak yang akan memberikan dananya(menanam modal) kepada perusahaan. Untuk itu pihak investor memerlukan laporan keuangan yang berfungsi agar investor mengetahui apakah dana atau modal yang ditanamkan ke perusahaan tersebut digunakan dan dikelola dengan baik. Dari hasil analisis tersebut pihak investor akan dapat menentukan langkah-langkah yang akan diambil selanjutnya yang akan ditempuh terhadap perusahaan tersebut. 


\section{Pemerintah}

Pemerintah terutama bagian pajak juga ikut andil dan berkepentingan terhadap laporan keuangan perusahaan. Mereka akan melihat laporan keuangan yang telah dibuat oleh perusahaan untuk menentukan nilai pajak yang akan dibayarkan oleh perusahaan.

\section{Karyawan}

Pihak karyawan atau pegawai juga membutuhkan Laporan Keuangan perusahaan yang berfungsi sebagai penentu langkah selanjutnya, apakah akan berpindah profesi atau tetap melakukan pekerjaannya. Jika laporan keuangan perusahaan baik dan memperlihatkan laba atau keuntungan yang besar maka karyawan bisa meminta kompensasi yang lebih pada perusahaan. Karena karyawan merupakan sumber daya penggerak perusahaan yang paling penting juga. Dengan melihat laporan keuangan perusahaan juga bisa memberikan informasi terkait kinerja karyawan tentang kemajuan dan apa yang perlu mereka perbaiki.

\section{Jenis-jenis Laporan Keuangan}

\section{Laporan Neraca}

Laporan neraca adalah laporan yang dapat digunakan perusahaan untuk menentukan bagaimana perusahaan memenuhi kewajiban keuanganperusahaan. Neraca akan membantu pemilik atau pihak-pihak yang berkepentingan lainnya untu mengevaluasi posisi keuangan perusahaan secara keseluruhan dan kemampuannya untuk membayar biaya kebutuhan maupun operasional. Berikut beberapa hal yang ada dalam laporan neraca:

- Aset merupakan harta atau kekayaan yang dimiliki oleh perusahaan. Aset terbagi menjadi dua yaitu aset lancar seperti kas, perlengkapan dan beberapa aset lainnya 
yang bisa habis. Kemudian aset tetap seperti tanah, bangunan, kendaraan dan lain sebagainya.

- Kewajiban (Likuiditas) merupakan biaya yang harus dipenuhi atau dibayar oleh perusahaan. Kewajiban atau utang ini seperti utang jangka panjang dan utang jangka pendek. Utang jangka panjang adalah kewajiban yang jatuh periode setelah satu tahun. Sedangkan utang jangka pendek adalah kewajiban yang jatuh tempo dalam jangka satu tahun.

- Modal (Ekuitas) adalah dana awal perusahaan. Modal yang akan dituliskan nilainya kedalam neraca adalah sisa setelah dikurangkan dengan kewajiban dari aset.

\section{Laporan Laba-rugi}

Laporan laba-rugi adalah laporan yang tujuannya untuk mengetahui apakah perusahaan mendapatkan keuntungan atau malah sebaliknya dalam satu periode tertentu. Laporan laba-rugi ini melaporkan ringkasan tentang pendapat perusahaan, kerugian, keuntungan, pengeluaran, dan pendapatan bersih yang didapatkan perusahaan. Hal yang terdapat dalam laporan laba-rugi adalah sebagai berikut :

- Pendapatan (Revenues) merupakan jumlah atau hasil yang diperoleh dari penjualan barang atau jasa.

- Beban (Expenses) merupakan biaya yang ditanggung perusahaan selama melakukan usahanya seperti biaya pajak, biaya listrik dan telepon, biaya gaji karyawan dan lain sebagainya. 


\section{Laporan Arus Kas}

Laporan arus kas adalah laporan yang melaporkan kas yang digunakan dan dihasilkan oleh perusahaan selama satu periode tertentu. Ada tiga hal yang terdapat dalam laporan arus kas yaitu:

- Aktivitas Operasi merupakan aktivitas penghasilan yang didapatkan oleh perusahaan kecuali pendanaan atau investasi, baik itu aset lancar atau kewajiban lancar(jangka pendek).

- Aktivitas Investasi adalah pencatatan yang dilakukan dari pelepasan aset jangka panjang daninvestasi lain yang tidak termasuk dalam setara kas.

- Aktivitas Pendanaan merupakan arus kas yang menghasilkan perubahan dalam ukuran dan komposisi modal ekuitas yang dikontribusikan atau pinjaman entitas seperti obligasi, saham dan dividen.

\section{Laporan Perubahan Modal}

Laporan perubahan modal adalah laporan yang berisi informasi tentang modal yang dimiliki perusahaan dan berisi hal-hal yang membuat modal tersebut berubah, baik itu bertambah atau berkurang dalam satu periode tertentu. Berikut hal-hal yang terdapat dalam laporan perubahan modal :

- Modal awal adalah modal pertama yang dimiliki oleh pemilik perusahaan yang tercermin dalam laporan keuangan sebelumnya.

- Modal investasi pemilik adalah jumlah modal atau dana yang berasal dari pemilik selama satu periode tertentu.

- Perolehan laba atau rugi adalah hasil dari laba bersih atau rugi bersih sepanjang waktu tertentu, diambil dari laporan laba rugi. 
- Pengambilan pribadi pemilik (prive) adalah jumlah uang yang diambil oleh pemilik untuk kepentingan pribadinya dalam satu periode tertentu.

- Modal akhir adalah modal yang didapatkan perusahaan pada akhir periode. 


\section{BAB III}

\section{PENUTUP}

\section{A. Kesimpulan}

Laporan Keuangan merupakan salah satu aspek penting yang perlu disusun secara terperinci oleh pihak manajemen yang telah ditentukan oleh perusahaan. Laporan keuangan bertujuan untuk memberikan informasi tentang posisi keuangan selama satu periode tertentu, juga bertujuan untukpihak-pihak yang berkepentingan seperti, pemegang saham, manajemen, kreditor, investor, pemerintah, dan karyawan.

Dalam laporan keuangan terdapat beberapa jenis laporan keuangan dengan masing-masing tujuan dan kegunaannya masing-masing untuk perusahaan.

- Laporan neraca (Aset, Kewajiban, Modal).

- Laporan Laba-Rugi (Pendapatan, Beban-Beban).

- Laporan Arus Kas (Aktivitas Operasi, Aktivitas Investasi, Aktivitas Pendanaan).

- Laporan Perubahan Modal (Modal Awal, Modal Investasi, Laba-rugi, Prive, Modal akhir).

\section{B. Saran}

Dengan membaca makalah ini diharapkan kita mampu memahami lebih jauh tentang Menyusun Laporan Keuangan, walaupun penulis menyadari bahwa dalam penulisan makalah ini masih terdapat banyak kekurangan. Untuk itu, penulis menyarankan agar mencari referensi-referensi bacaan lebih banyak lagi selain dari makalah ini. 


\section{DAFTAR PUSTAKA}

Andarsari, P. R. (2016). Laporan Keuangan Organisasi Nirlaba (Lembaga Masjid). Jurnal Ekonomi Universitas Kadari , 1 (2), 143-152.

Diajeng Amatullah Azizah Rachmanti, d. (2019). Analisis Penyusuna Laporan Keuangan UMKM Batik Jumput Dahlia Berdasarkan SAK-EMKM. Jurnal Balance , 16 (1), 31-52.

Hery Pandapotan Silitonga, d. (2020, July 1). Dasar-Dasar Analisa Laporan Keuangan. Retrieved Desember 12, 2021, from https://repository.penerbitwidina.com/publications/321987/dasardasar-analisa-laporankeuangan.

Hidayat, R. (n.d.). Makalah Laporan Keuangan. Retrieved Desember 12, 2021, from https://www.academia.edu/9973837/Makalah_Laporan_Keuangan.

Sulistiyowati, L. (2010). Memahami Laporan Keuangan. Jakarta: PT Elex Media Komputindo.

Trianto, A. (2017). Analisis Laporan Keuangan Sebagai Alat Untuk Menilai Kinerja Keuangan Perusahaan Pada PT. Bukit Asam (Persero) TBK Tanjung Enim. Jurnal Ilmiah Ekonomi Global Masa Kini , 8 (03), 1-10. 